\title{
A qualitative study of teacher talk in an EFL classroom interaction in Aceh Tengah, Indonesia
}

\author{
Chairina Nasir, Yunisrina Qismullah Yusuf*, and Andri Wardana \\ Department of English Education, Faculty of Teacher Training and Education, Universitas Syiah Kuala, \\ Jalan T. Nyak Arief, Darussalam, Banda Aceh 23111, Indonesia
}

\begin{abstract}
Teacher talk plays an essential role in classroom interaction since it can facilitate students to enhance their levels of comprehension toward the learning materials and further encourage them to be more active during the learning process. This qualitative study is aimed to analyze the types of talk employed by the teacher in the classroom interaction based on the framework of Flanders Interaction Analysis Category System (FIACS) promoted by Flanders (1970). The data were collected through audio recording and observation for three class meetings, and interview with the teacher at the second grade of a senior high school in Aceh Tengah, Indonesia. The results showed that all of the seven types of teacher talk were found. Among them, giving directions took place as the most applied interaction by the teacher. It indicates that the teacher mostly controlled and provided the students with directions, commands, or orders in the learning process. Meanwhile, the least used were accepting or using ideas of pupils and accepting feelings. From the result of the interview, this matter occurred due to the lack of students' participation in expressing their ideas and feelings. Thus, this study is expected to be a reference by which teachers could consider the types of teacher talk to be implemented to improve their students' activity and interest during the classroom interaction.

Keywords: Classroom interaction; EFL students; FIACS; teacher talk

\begin{tabular}{|c|c|c|}
\hline $\begin{array}{l}\text { First Received: } \\
\text { 28 February } 2018 \\
\text { Final Proof Received: } \\
\text { 25 January } 2019\end{array}$ & $\begin{array}{c}\text { Revised: } \\
17 \text { August } 2018\end{array}$ & $\begin{array}{c}\text { Accepted: } \\
\text { 30 November } 2018 \\
\text { Published: } \\
\text { 31 January 2019 }\end{array}$ \\
\hline $\begin{array}{l}\text { How to cite (in APA style): } \\
\text { Nasir, C., Yusuf, Y. Q., \& Wardana } \\
\text { classroom interaction in Ace } \\
\text { Linguistics, } 8,525-535 . \text { doi: } 10\end{array}$ & $\begin{array}{l}\text { (2019). A qu } \\
\text { Tengah, Indo }\end{array}$ & $\begin{array}{l}\text { study of teacher talk in an EFL } \\
\text { Indonesian Journal of Applied }\end{array}$ \\
\hline
\end{tabular}
\end{abstract}

\section{INTRODUCTION}

In the EFL classroom, one of the most important parts of the teaching and learning process is the interaction that occurs between teachers and learners. Yanita, Yusuf, and Gani (2016) believed that among the success of a teacher's teaching is the quality of his or her interaction with the students. Brown (2007) coined interaction as a collaborative exchange of thoughts, feelings or ideas between a teacher and learners or a learner and other learners resulting in a reciprocal effect on each other. Hence, it can be concluded that interaction in a language classroom is the process of learning a language. In relation to the importance of interaction, Long (1996, as cited in Masrizal, 2014) argued that interaction facilitates acquisition because of the conversational and linguistic modifications that occur in such discourse and provide learners with the input they need. Therefore, supposedly an ideal classroom interaction needs to provide students with discussions that encourage them to practice the language and facilitate their inquiries and put some responsibility for their learning. In this sense, teacher talk should occur to facilitate learner and not to dominate the teaching-learning process. Though so, some studies showed how classroom interaction of English subject in Indonesia is very much controlled and dominated by teachers (Milal, 2011). Maulana, Opdenakker, Stroet, and Bosker (2012) in their study

\footnotetext{
* Corresponding Author

Email: yunisrina.q.yusuf@unsyiah.ac.id
} 
also found out that Indonesian teachers hardly had interaction with students. They spend most of the time lecturing with little acknowledgment of students' learning process, students mistakes, and misconceptions (Suryati, 2015). Therefore, the goal of language learning is not fully achieved. Harmer (2007) stated that the overuse of Teacher Talking Time (TTT) is inappropriate since the more the teacher talk, the less chance for students to practice their language. Harmer (2007) further argued that the most important thing in classroom interaction is not the quantity of teacher talk but how the teacher provides comprehensible input that assists the learners to understand and acquire the language.

Drawing from the concepts of ideal classroom interaction with a balanced proportion of teacher talk and the problems rose from fewer students' participation in the classroom interaction, this study aimed at analyzing types of teacher talk in an English class of a senior high school in Takengon, Aceh Tengah, Indonesia. Our preliminary observation has shown that that in some senior high schools in Aceh Tengah, the classrooms were less active and students were seemed not to be given the opportunities needed to develop their English communication. Therefore, there is a need to study these teacher-students interaction further so that later on, solutions to problems arising from the condition can be pursued effectively. Thus far, no related published work has been done in this school to study the classroom interaction, specifically on teacher talk. We applied the Flanders Interaction Analysis Category System (FIACS) as this framework was deemed suitable to be used in this study. A number of studies have also used this framework to analyze their data on teacher talk (see Hai \& Bee, 2006; Nurmasitah, 2010; Saba, 2007).

\section{Research objective}

Hence, the research question of this study is formulated as follows: What are the types of teacher talk that occurred in the classroom interaction based on the framework of Flanders Interaction Analysis Category System (FIACS) at the senior high school? We hope that the results of this study can draw attention to other EFL teachers on types of teacher talk in the language classroom and decide the balance proportion of teacher talk, so students get the best of a language learning experience.

\section{Teacher talk}

Teacher talk has been defined in many different perspectives. Yanfen and Yuqin (2010) defined teacher talk as the most language used by the teacher in the classroom to provide directions, describe activities and examine students' comprehension towards the lesson being taught and learned. In relation to this definition, Walsh (2002, p. 3) alluded that teachers' choice of language and their capacity to control the language use are crucial to facilitate or hinder learners' participation in classroom interactions. Besides, the teachers' verbal behaviors improve the level of learners' participation such as applying open and direct approaches to error correction, using of real-life conversational language appropriately when giving feedback, allowing extended wait-time for learners' responses, scaffolding by providing needed language to pre-empt communication breakdowns and offering communication strategies to maintain and extend learners' turns (Tuan \& Nhu, 2010, p. 39).

From the definitions above, it can be concluded that as a pivotal part of foreign language teaching, teacher talk has its own features in both the content and the medium of the target language. The language used by teachers in language classes is served as the source of input of language knowledge and also used to instruct language communication and organize classroom activities. Thus, it is inevitable that teacher talk plays an essential role in the teaching process as an interactive device.

Chaudron (1988, as cited in Wang, 2014, p. 1172) pointed out the features of teacher talk: the speed of teacher talk seems slower, more frequency of pause showing speakers' thinking or conceiving and with longer time, clearer and more understandable pronunciation, easier chosen vocabulary, with lower subordinate degree (less use of subordinate clause), more narrative sentences or declarative sentences than interrogative sentences, and more frequency of teachers' self-repetition. These features indicate that teacher talk is simplified codes which aim to provide maximum comprehensible input for language learners so that teachers and students can maintain an unobstructed channel of communication.

According to Krashen's (1982) theory in the term of input hypothesis, learners cannot acquire a foreign language unless they get comprehensible input as much as possible. It can be inferred that the only way of acquiring language is to obtain comprehensible input. Krashen (1982) further explained that comprehensible input could be formulated as ' $i+1$ '; ' $i$ ' shows the present level of learners while ' 1 ' shows the language knowledge which is a little more than learners' present level; it means that if learners can be exposed to plenty of ' $i+1$ ' in the process of acquisition, they can insensibly acquire new language knowledge while understanding information. Accordingly, in a second or foreign language classroom teaching, teacher talk (TT) is the one of the largest as well as the most reliable source of learners' input (Wang, 2014, p. 1172). If comprehensible teacher talk as input is enough in the classroom, that is to say; teachers can adjust their talk to learners' present or a little higher level, learners can learn faster and better.

\section{Teacher talk in FIACS}

In relation to creating an interactive foreign language classroom, it is important to pay attention to the types of teacher talk employed by the teacher in the classroom. This is as supported by Yanfen and Yuqin (2010) who stated that the appropriate teacher talk could create 
harmonious atmospheres, and at the same time, promote a more friendly relationship between teachers and students, and consequently create more opportunities for interactions between the teachers and the students. Flanders (1970, p. 5) as quoted in Hai and Bee (2006), in his Flanders Interaction Analysis Category System (FIACS) classified teacher talk into seven types in two categories: direct influence and indirect influence. Those types of direct influence are as follows.

1. Lecture: the teacher gives facts or opinions about content or procedure expression of his own ideas, gives his own explanation or cites an authority other than a pupil.

2. Giving directions: the teacher gives directions, commands or orders or initiation with which a student is expected to comply with.

3. Criticizing or justifying authority: this is intended to change students' behavior from non-acceptable to acceptable pattern. When the teacher asks the students not to interrupt with foolish questions, then this behavior is included in this category. The teacher's 'what' and 'why' also come under this category.

Meanwhile, the types in the indirect influence are as the following.

4. Accepting feelings: the teacher accepts the feelings of students in a non-threatening manner, and the teacher feels that they should not be punished for exhibiting their feelings. Feelings may be positive or negative; predicting and recalling feelings are also included.

5. Praise or encouragement: the teacher praises or encourages students' action or behavior. For example, when a student gives an answer to the question asked by the teacher, the teacher gives positive reinforcement by saying words like 'good,' 'very good,' 'better,' 'correct,' 'excellent,' 'carry on,' etc. In addition, jokes that release tension, not at the expense of another individual, nodding head or saying 'uh-huh?' or 'go on' are also included.

6. Accepting or using ideas of pupils: the students' ideas are accepted only and not his feelings. If a pupil passes on some suggestions, then the teacher may repeat in a nutshell in his own style or words. The teacher can also clarify, build or develop ideas or suggestions given by a student.

7. Asking questions: the teacher asks questions about content or procedures based on his or her ideas and expects an answer from the students. Sometimes, the teacher asks the question, but he or she carries on his lecture without receiving any answer, then such questions are not included in this category.
While FIACS is meant for all the subjects taught in the classroom, there are also other systems of observation for English Language Teaching. Some of them are Brown Interaction Analysis System (BIAS) and Moskowitz's Foreign Language Interaction (FLINT). Thus, FIACS have been widely used by researchers in analyzing the system of interaction to study the happenings in a classroom when a teacher teaches. This system has been widely used for observing classroom interaction and becomes the basis for many other systems developed later on.

Among them is a study by Nurmasitah (2010) who investigated teacher talk in a Geography class at a senior high school in Semarang, Indonesia; she revealed that most of the teacher's talking time was devoted to asking questions and lectures. She further explains that the teacher talked for more than $50 \%$ of the time, while the students talked for only about $20 \%$ of the lesson time. Nevertheless, even though the teacher-dominated the talking time, the students were active enough during the classroom interaction. In terms of the type of teacher talk used, which was also based on Flander's (1970) framework, her study shows that the teacher had used more direct influence (lecturing, giving directions and criticizing or justifying authority) compared to indirect influence (accepting feeling, praises or encourages, accepting or using ideas of students, and asking questions).

Another study by Aisyah (2016), focused on the teacher talk in an EFL class of tenth graders and reasons for the teacher in choosing the type of teacher talk to use in the classroom. From five meetings of observations, recording and finally an interview with the teacher at the end, the data were then analyzed by also using the framework of Flanders (1970). The results revealed that all types of teacher talk occurred in the classroom by asking questions (a type in indirect influence) as the most dominant used by the teacher. Aisyah (2016) claimed this was because the materials given by the teacher to the students were in the form of writing and reading comprehensions. Therefore, to have the teacher talk more than the students to explain the material were deemed necessary. From the interview, the teacher informed her that all types of teacher talk happened naturally by considering the learning situation that took place.

Then, a study in Bengkulu, Indonesia, by Putri (2014) also found that even though the teachers under her study used more of their time talking to lecture, but also to ask questions to their students. This is based on her data from observations of seven class meetings from two teachers teaching English in a junior high school. Based on Flanders (1970), this means that direct influence was done more compared to indirect influence. Thus, she concluded that the students were not active enough in the classroom interaction.

Accordingly, the aforementioned studies and a lot more imply that the teachers still dominate the talking time during classroom interaction. In fact, Setiawati (2012) claimed that despite the teacher talk is good, 
especially for young learners; thus her study reveals that students find their classes to be more motivating, interesting, and challenging when the teachers minimized their talking and presented more interesting activities. She deduces that teacher talk does not only serve as a medium to achieve the learners' learning aims but it is also an instrument to develop dynamic interaction between teachers and students in the classrooms.

\section{METHOD}

The research method applied in this study was qualitative. In dealing with the research design, we used a descriptive design supported by a simple statistic calculation (percentage) to describe the findings. Pertaining to this matter, Alwasilah (2002) asserted that the descriptive design is used to describe the characteristics of the researched objects. Here, it is referred to describe the distribution of each type of teacher talk that occurred in the classroom interaction based on the framework of FIACS.

We had recorded a teacher by audio recording with her consent, and also her students in the class while teaching English to her eleventh-grade students at a senior high school in Aceh Tengah, Indonesia. There were 30 students in her English class. We recorded the classroom interaction for three meetings by placing a video recorder at one of the back corners of the classroom. Each meeting lasted for 90 minutes and thus making a total of 270 minutes of recording. At the same time, the fourth writer became a non-participant observer by positioning and sitting next to the video recorder to observe the classroom interaction by using observation sheets. An example of the observation used for each classroom meeting is shown in Figure 1. It is adapted from Flanders (1970, in Hai \& Bee, 2006, p. 118).

\begin{tabular}{|c|c|c|c|c|}
\hline \multicolumn{5}{|c|}{$\begin{array}{l}\text { Class: } \\
\text { Topic: } \\
\text { Day/Date: } \\
\text { Duration: }\end{array}$} \\
\hline \# & Aspects to be observed & Yes & No & Extra notes \\
\hline 1 & Accepts Feelings & & & \\
\hline 2 & Praise or Encouragement & & & \\
\hline 3 & Accepts or Uses ideas of Pupils & & & \\
\hline 4 & Asking Questions & & & \\
\hline 5 & Lecture & & & \\
\hline 6 & Giving Directions & & & \\
\hline 7 & Criticizing or Justifying Authority & & & \\
\hline
\end{tabular}

Figure 1. Observation sheet (adopted from Flanders, 1970, in Hai \& Bee, 2006, p. 118).

In addition, we further interviewed and recorded the teacher to support the findings by asking questions related to the teacher talk in the teaching and learning process in her classroom interaction. The questions asked to the teacher were also adapted from Flanders (1970, as cited in Hai \& Bee, 2006, p. 118) with some adjustments to suit the needs of this research. They are:

1. From the seven types of teacher talk (i.e., accepting feelings, praise or encouragement, accepting or using an idea of students, asking questions, lecture, giving directions, and criticizing or justifying authority), which type do you use most in your classroom interaction?

2. Why do you choose that type?

3. When do students respond and ask questions in the classroom interaction?

4. How do the students respond and ask questions in the classroom interaction?

5. If students do not ask questions, does this mean that they already understood (your lesson) or vice versa?

6. What do you do to make the students ask you questions?
For analysis, we had had firstly transcribed the recording from the video recorder. In transcribing these data, we applied some strategies from Ali (2000), such as keeping the transcription as simple as possible, labeling the speakers using letters and numbers, numbering the lines or clauses, inserting contextual information to explain essential aspects, e.g. non-verbal interaction and using ordinary orthographic transcription, with conventional punctuation when appropriate.

After the data of audio-recording were transcribed, they were encoded into the categories of teacher talk based on FIACS. As suggested by Alwasilah (2002, p. 159) that coding and analyzing the data help the researcher in (1) identifying a phenomenon, (2) counting the frequency of a phenomenon, (3) showing the relation of code frequencies with inclination of findings, and (4) arranging the categorization and subcategorization. Accordingly, in order to classify the types of teacher talk accurately, the researcher applied the coding guidance of FIACS (see Table 1) adapted from Hai and Bee (2006, p. 117). 
Table 1. Coding guidance of teacher talk in FIACS (adapted from Hai \& Bee, 2006, p. 117).

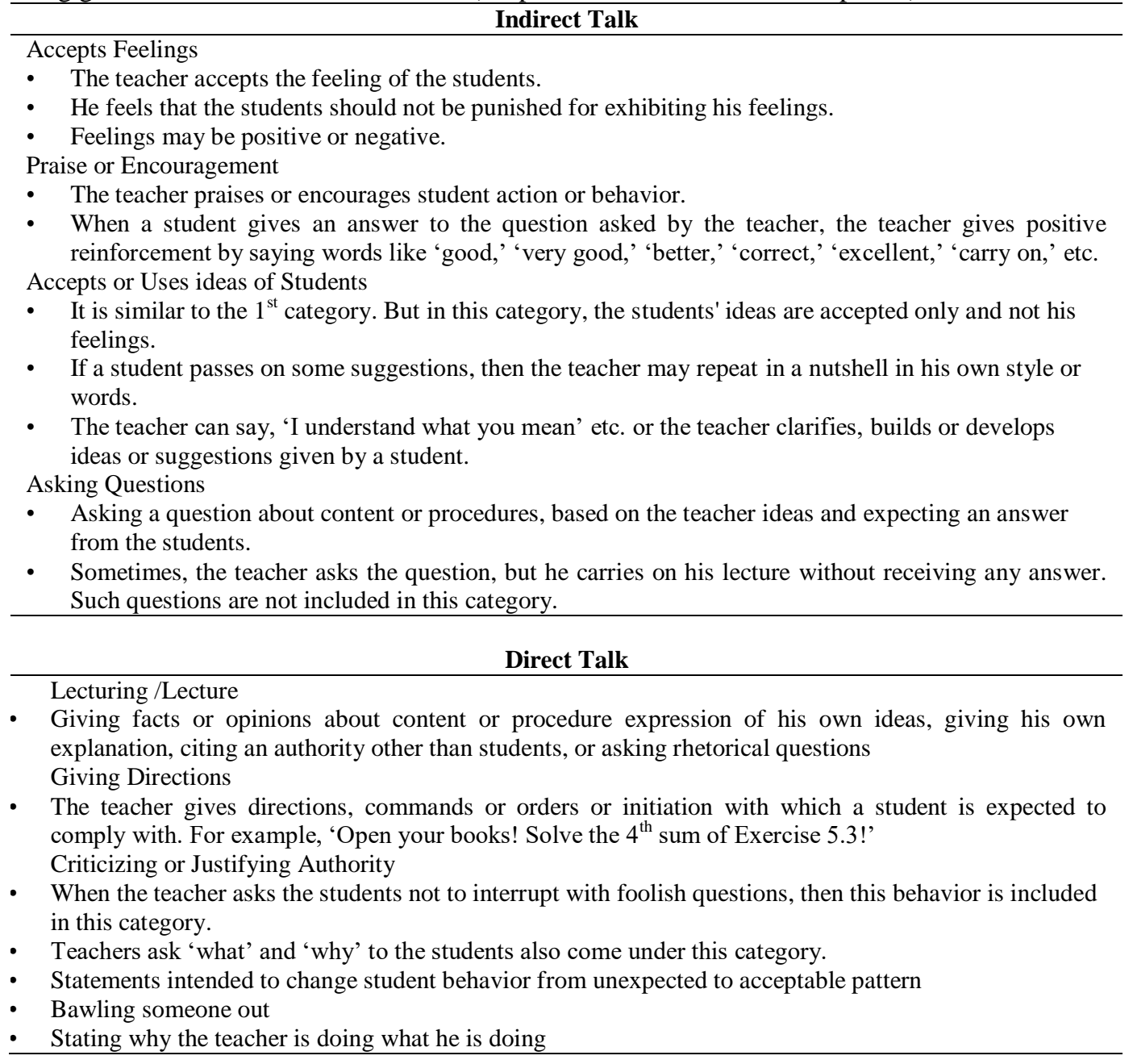

After transcribing and coding into the abovementioned categories, the next step was calculating the amount and the percentage of each category. Although this research used qualitative research design, simple statistics was also needed in order to help the researcher reveal the amount and the percentage of teacher talk categories used in the classroom. Chambliss and Schutt (2013) put forward a way of calculating the percentage, which is by dividing the frequency of cases in a particular category by the total number of cases and multiplying by 100 . The formula or equation is:

$$
P=\frac{f}{N} \times 100
$$

Where:

$P=$ Percentage of the category being computed

$f=$ The frequency of the category being computed

$N=$ The total number of cases

The data from observation were cross-checked with the data from the transcription and interview. Regarding the data obtained from the interview, we also transcribed them. The transcription was explored and coded to get the teacher's inner thought towards the use of the types of teacher talk in classroom interaction. The gained data were then validated with the previous data from the classroom observation and audio recording. This is in accordance with the statement of Baxter and Jack (2008) that, in a qualitative study, data from multiple sources are then converged in the analysis process, rather than handled individually. They also claim that each data source is one piece of the puzzle, in which each piece contributes to the researcher's understanding of the whole phenomenon (Baxter \& Jack, 2008).

Finally, the last step in data analysis was interpreting the data, in which we described the findings narratively to answer the research question of this study. The interpretation included the description of what have been found, the analysis of categories, and the conclusions of those interpretations based on our points of view and the theories underlying it.

\section{FINDINGS}

From the observation and audio recording of three meetings of the teacher teaching her class or approximately 270 minutes, Figure 2 shows the result of teacher talk based on the types by FIACS in percentage. 
Figure 2 shows that giving directions was the most dominant type of teacher talk applied in classroom interaction with 52 occurrences $(36.3 \%)$. It is followed by asking questions with 41 occurrences $(28.7 \%)$, praise or encouragement with 20 occurrences (14\%), lecture with 14 occurrences $(9.8 \%)$, criticizing or justifying authority with 9 occurrences $(6.3 \%)$, accepts or uses ideas of pupils with 6 occurrences $(4.2 \%)$, and the least aspect in teacher talk was accepts feelings with only 1 occurrence $(0.7 \%)$.

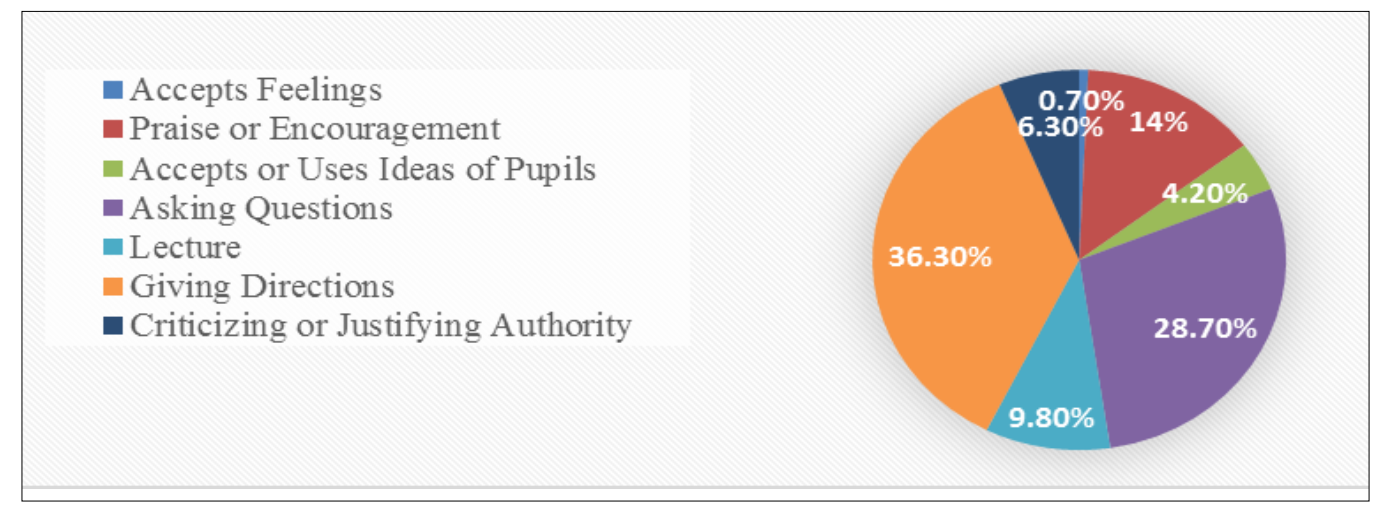

Figure 2. The frequency of teacher talk types

Figure 2further indicates that the proportion of indirect talk in the classroom interaction was lower than direct talk. Overall, $47.6 \%$ of teacher talking time was used for the indirect talk. This denotes that the teacher spent less indirect talking time such as accepts feelings, praise or encouragement, accepts or uses ideas of students, and asking questions during the teaching and learning process. The results of indirect talk use can be seen in Table 2.

Table 2. The percentage of indirect talk

\begin{tabular}{llrc}
\hline Types of teacher talk & Percentage & Total Percentage \\
\hline Indirect talk & 1. Accepts feelings & $0.7 \%$ & $47.6 \%$ \\
& 2. Praise or encouragement & $14 \%$ & \\
3. Accepts or uses ideas of pupils & $4.2 \%$ & \\
4. Asking questions & $28.7 \%$ & \\
\hline
\end{tabular}

Compared to the proportion of indirect talk in Table 3, we found that the direct talk percentage was a bit larger (see Table 3). This signifies that the model of teaching and learning process in this study still focused on the teacher, or known as teacher-centered. The proportion of direct talk interstitially dominated the teacher talking time (52.4\%). The teacher's activity was more in the lecture, giving directions, and criticizing or justifying authority.

Table 3. The percentage of direct talk

\begin{tabular}{llrc}
\hline \multicolumn{2}{c}{ Types of teacher talk } & Percentage & Total percentage \\
\hline Direct talk & 1. Lecture & $9.8 \%$ & $52.4 \%$ \\
& 2. Giving Directions & $36.3 \%$ & \\
3. Criticizing or Justifying Authority & $6.3 \%$ & \\
\hline
\end{tabular}

Furthermore, from observations, it was discovered that the teacher also used non-verbal communications such as giving various gestures, smiling, walking, and pointing, etc. Nonetheless, these actions were not taken into account since they were not included in the seven types of teacher talk based on the framework of this present study. The next following sub-sections illustrate the types of teacher talk found in data.

\section{Giving directions}

The most used type of teacher talk was giving directions with $36.3 \%$. From the recording, the researcher found that the teacher usually gave directions to the students. Excerpt 1 is an example from the data ( $\mathrm{T}$ refers to the English teacher, and $\mathrm{S}$ refers to a student).

\section{Excerpt 11}

$\mathrm{T}$ :Sekarang diskusikan dengan pasangannya tentang makna dari setiap ekspresi yang ada di papan tulis! [Now, please discuss with your pair about the meaning of each expression on the whiteboard!]

As the dominant type of teacher talk found in this study, giving directions means that the teacher gave instructions, commands, or orders to which the students were expected to comply with. She gave directions when she asked the students to do assignments or tasks and to answer the questions. This finding was similar to Aisyah (2016) who also found giving directions to be the most used in the EFL class under her study. Perhaps since both focus on EFL students, this type was mostly 
used since learning a foreign language surely requires more guidance and directions from the teacher. This is though different from Nurmasitah (2010) who pointed out that giving direction was one of the least types used in the classroom interaction in her study. This meant that the teacher used a little time to control the students during the teaching and learning process. We assume this difference is due to the different class, in which her study observed students in Geography; meanwhile, this study focused on an English class.

\section{Asking questions}

At $28.7 \%$, asking questions appeared as the second dominant type of talk used by the teacher. Regarding this category, the researcher found that the teacher intentionally asked questions and expected the answers from students. Here is an example from the data.

\section{Excerpt 2}

T: Apa makna dari 'calming someone down'? [What is the meaning of 'calming someone down'?]

\section{S: Meredakan marah. [Alleviating anger.]}

In Excerpt 2, the teacher wanted to check the students' understanding of the English phrase. This is typical conduct in this type of talk where the teacher asks some questions related to the material and is intended to gain the students' responses. Asking questions can assist teachers in knowing whether their students' understanding of the lessons is on the right track (Park, 2005). However, this type of talk could be considered a kind of display questions simply to check students' comprehension and required them to recall facts. Display questions are less encouraging to promote students' active participation compared to referential questions as students are given the opportunity to make inferences and judgments (Suryati, 2015).

\section{Praise or encouragement}

This type, as the third used type by the teacher in teaching, was at $14 \%$ of occurrences during her teaching. It was observed that when a student answered her question, she would give praises or encouragement to the student. An example from data is as the following.

\section{Excerpt 3 \\ T: Ya, bagus sekali! Excellent! [Yes, very good! Excellent!]}

Excerpt 3 is an example of praise and encouragement to the student from the teacher after the student responded correctly to the teacher's question. This type of talk is usually intentional because a conscious positive reward and reinforcement to the students help them gain their interest in the subject being studied.

It is important that teachers provide positive feedback to the students' responses in the classroom because it can generate motivation and interest in the lessons (Díaz-Ducca, 2014). Despite the claim that there is a difference between praise and encouragement where praise is associated with authoritarian approach and encouragement reinforces effort or process (Dinkmeyer \& Dreikurs, 1963, as cited in Cope, 2007), but Reigel (2005) had also found that praise can be an evaluative feedback of a positive affective nature. Therefore, teachers must be evaluative in providing praise or encouragement for their students so that teachers can ensure that they allow students "to reflect, to move to the next learning or behavior step, to become risktakers, to grow self-efficacy, and become autonomous learners" (Ferguson, 2013, p. 39). Ferguson (2013) further noted that to praise for the effort is more important than ability or performance, so students do not feel controlled or manipulated in the classroom.

\section{Lecture}

The lecture was applied by the teacher in the classroom interaction for $9.8 \%$. She applied lecture because this was essential in explaining the learning materials so that the students understood and not confused about what was actually being learned. E5 illustrate this type of teacher talk from the data.

\section{Excerpt 4}

$\mathrm{T}$ : Well, the correct answer is that kelinci itu sudah mati bukan karena anjing itu. Jadi, dia memang sudah mati sebelum dia digigit oleh anjing tersebut. [Well, the correct answer is that the rabbit was already dead (and it is) not because of the dog. So, the rabbit was already dead before it was bitten by the dog.]

Based on Excerpt 4, the lecture was used since the teacher wanted to explain the contents of the lesson since before this talk occurred, there was a student who asked a question about the rabbit that died and he seemed confused on who caused it. Furthermore, we also find that the lecture was also applied to explain the learning objectives of the class. This situation has been found to be quite common in Indonesian English classrooms, where teachers still use most of their time in the classroom for lecturing (Maulana, et al., 2012; Suryati, 2015). The reasons vary from teachers who do not make an effort to create an interactive classroom to students who lack the competence in speaking and courage that cause the classroom to be passive.

\section{Criticizing or justifying authority}

Criticizing or justifying authority occurred for $6.3 \%$ in the data. We found that this type was employed when the teacher criticized the student's inappropriate behavior. The example is as follows:

\section{Excerpt 5}

T : You always come in late. Dari mana kamu? Apa kamu tidak dengar bel berbunyi? Kalau telat sekali lagi, saya palang absen! [You always come in late. Where have you been? 
Did you hear the bell rang? If you come late again, I will consider you absent (from class).]

Excerpt 5 demonstrates criticism from the teacher towards a student who was not discipline. The teacher also used her authority to make them discipline and follow the school regulations. The teacher only employed this type when she found the students to be noisy in class, out of control, to get their attention or when she criticized the students' responses towards her questions. Nevertheless, Gharbavi and Iravani (2014) reminded that teachers should be careful when providing criticisms to their students; the comments should not leave them with feelings of being hurt or bad effects on their behavior.

\section{Accepts or uses ideas of pupils}

From the data, it was found out that accepts or uses ideas of pupils occurred for $4.2 \%$. It was the second least type of talk used by the teacher. An example in data (see E6) showed a case when a student expressed his ideas, the teacher accepted and developed his ideas in her own words.

\section{Excerpt 6}

$\mathrm{T} \quad$ : Baik, saya akan bagi kalian menjadi four groups. [Okay, I will divide you into four groups.]

$\mathrm{S} \quad$ : Bu, laki-laki dengan kelompok laki-laki saja ya, perempuan juga begitu. [Miss, the boys shall be with the boys, and the girls, too.]

$\mathrm{T} \quad$ : Ya, kalian akan dibagi dua grup laki-laki dan dua grup perempuan. [Yes, you will be divided into two male groups and two female groups.]

In Excerpt 6, it is clear that the teacher employed this type of talk to agree with a student's idea about the group division; that males should be separated from the females. She had repeated or developed the student's idea by generating them into her own words. This type is known to increase students' confidence and generate a more interactive classroom.

In this category, the students' ideas are accepted and not his feelings (Hai \& Bee, 2006). And so, if a student pitches in some suggestions, then the teacher may recap in his or her own style or words. He or she can also clarify, build or further develop the ideas or suggestions given by the student. Moreover, besides acceptance through verbal actions, acceptance could also be seen through the non-verbal actions, and this is noticed when she nodded or smiled towards their responses, comments or suggestions. Thus, she would express her disagreement by giving a frown or shook her head or finger.

\section{Accepts feelings}

Accept feelings occurred for $0.7 \%$ in the classroom interaction. It was the least type used by the teacher. From the data, we found that this type occurred because the teacher felt that the student deserved to express his feeling on what he was facing during the learning process.

\section{Excerpt 7}

$\mathrm{S} \quad$ : Kami tidak bisa menyelesaikannya. Soalnya susah, Bu. [We can't finish it. The questions are difficult, Miss.]

$\mathrm{T} \quad$ : Saya mengerti, tapi ini nanti akan menarik ketika kalian main gamenya. [I understand, but it will be interesting when you play the game later.]

In Excerpt 7, the teacher accepted the student's complaint on the game that was deemed difficult. Thus, she comforted him by accepting his feelings and encouraged him to try first before saying it was not easy to play the game. When a teacher accepts her students' feelings, this kind of action provides a safe environment for learning (Putri, 2014). She also showed this acceptance when she offered opportunities and chances for students in the class to conduct or say something for everyone in the class to see or hear.

In order to strengthen the data about the types of teacher talk that occurred in classroom interaction, we also interviewed the English teacher as the subject of this study. Six questions were asked to the teacher. They concerned with the types of teacher talk that the teacher frequently used and the happenings in the classroom interactions.

According to the teacher, from the seven types of teacher talk, she used praise or encouragement and asking questions more than other types, as stated in IE1 (IE refers and henceforth is referred to interview excerpt). The data from audio recording also noted asking questions and praise or encouragement to be the second and third most used type by the teacher in the classroom. Even though they were not the most dominant types used in the classroom, but they frequently occurred during the teaching and learning process.

IE1 : Mm, I think I mostly use praise or encouragement and asking questions. I use praise and encouragement to motivate my students while asking questions are to make sure that they have understood my lecture and the materials being taught and learned.

In IE1, the teacher asserted that she used praise or encouragement aspect more like the way to appreciate the students' work as well as to motivate them in enhancing their performance during the learning process. Moreover, she applied the asking questions aspect to check whether the students' have understood the lesson or not. She added that:

IE2 :The students rarely give responses and asking questions during the teaching and learning process. Just one or two students 
will and can do these after I ask them repeatedly.

IE3 : If they do not ask any questions, it means that they do not understand the lessons. Thus, I need to check their understanding of the whole materials by asking the same questions frequently.

Based on the data in IE2, the teacher informed that the students rarely responded to her questions. She assumed that this might be due to the fact that they have not grasped the lessons given to them in class. To overcome this problem, in IE3, she provided praise or encouragement and asked questions to stimulate her students' activity in classroom interaction. Thus, it can be inferred that asking questions was used as one of the teacher's efforts to generate the students' excitement to be more active during the classroom interaction as well as to interrogate their comprehension on what they have learned.

\section{DISCUSSION}

Based on the results of recording and classroom observation, it can be drawn that of the seven categories of teacher talk, giving direction was the most frequent category used by the teacher in classroom interaction (at $36 \%$ ). It means that the teacher gave directions, commands, or orders to which a student was expected to comply, which took a relatively immense proportion. She gave directions when she asked the students to do assignments or tasks and to answer the questions. This finding was significantly different with the research finding by Nurmasitah (2010), in which she pointed out that giving direction was one of the least types used in the classroom interaction, which meant that the teacher used a little time to control the students during the teaching and learning process.

The second most frequently used type was asking questions at $28 \%$. Here, the teacher usually asked some questions related to the material that was intended to gain the students' responses. This finding was quite similar to what Park (2005) revealed in his study that giving directions and asking questions are the most dominant types of teacher talk applied by teachers in primary EFL classrooms. Pertaining to this finding, the teacher in this study had explained the reasons why she preferred using such two types of teacher talk as previously stated in the interview findings, as these types helped her assess the students' understanding of the lessons. Therefore, by knowing their extent of comprehension, she can make decisions on what to do next to improve the teaching and learning process.

Meanwhile, from the result of the interview, it can be interpreted that the teacher dominated the classroom interaction by asking questions since the students barely gave responses and asked questions during the teaching and learning process. This matter is in line with the research findings of Menegale (2008), who also found that teachers still dominate the talking time in the classroom. Moreover, it coincides with the findings by Zambrano (2003), who asserted that in the classroom interaction, the cliché problem is having the teacher talk, for a great deal of time. Nevertheless, the teacher in this study provided her reasons for still dominating the classroom: this was because many students still had difficulty in understanding the lesson on her first lecture. Therefore, she subsequently needed to probe the students with questions to improve their comprehension of the lesson.

According to Nurmasitah (2010), if a teacher does more indirect talk in the teaching and learning process, it means that she allows the students to be active in her classroom. It is kind of student-centered model learning, in which the teacher only gives little explanation about the material, and then students have discussions with their friends or with the teacher. In the meantime, the results of this study showed that the proportion of indirect talk in classroom interaction was lower than the direct talk. Overall, $47.6 \%$ of teacher talking time was used for the indirect talk (see Table 3). Meanwhile, the proportion of direct talk at $52.4 \%$ slightly dominated the teacher talking time (see Table 4). It can be inferred that the teacher was still the center of the teaching and learning process, in which she spent more time talking than the students. Moreover, she used more direct talk that slightly discouraged the students from initiating talk in the classroom interaction.

To generate communicative interaction between the teacher and students was one of the obstacles occurring in the teaching and learning process of this study. During the teaching and learning process, sometimes there was a period of time in which the teacher did not get any responses from the students; even though the students knew and had the willingness to give responses. This is actually the time where she has to play her role as a controller and an initiator. For that reason, teachers have to implement interactive techniques and use various types of teacher talk which can run the teaching and learning process smoothly. As a result, both the teacher and students are able to negotiate meanings and collaborate to accomplish certain purposes during the teaching and learning process.

\section{CONCLUSION}

From 143 frequencies of teacher talk found in three classroom meetings, the results showed that giving directions $(36.3 \%)$ and asking questions $(28.7 \%)$ were mostly employed, and these were followed by praise or encouragement (14\%), lecture $(9.8 \%)$, criticizing or justifying authority $(6.3 \%)$, accepts or uses ideas of pupils $(4.2 \%)$, and accepts feelings $(0.7 \%)$. At the beginning of each class, giving directions was mostly employed to inform what the learners were going to learn and do in class that day. Moreover, asking questions was also dominantly applied to make the students attentive to the subject of discussion as well as 
to check their understanding of the topic. Accepting feelings and accepting or using ideas of pupils were the least used by the teacher because the students were less prompted to express their feelings or ideas.

Although in the interview the teacher claimed that she had done her best in using teacher talk to get the students to be active, she was still dominating the classroom since giving directions was the most used in class, perhaps without her being aware of it. However, she did mention that their lack of being active was due to their low competence in English. Based on her statement, it can be inferred that she, as the teacher, was still the center of the teaching and learning process in which she spent more time talking than the students. Since her students were less competent in using the learned language in class, she accordingly became more talkative in the classroom.

To have more direct talk led the students to be less engaged to talk in the classroom interaction. Perhaps, this is some of the causes that make less interactive English classrooms in Indonesia because students were not given enough opportunities to develop their English communication skill. Thus, English teachers are suggested to provide more indirect teacher talk to boost interactive classrooms, which can lead to an increase of motivations in learning the foreign language.

We recognize that the present study only focused on one teacher and three class meetings. Thus, it is recommended that future studies on a similar topic may consider a larger group of respondents and more classroom meetings so that the conclusions drawn from this study can be developed.

\section{REFERENCES}

Aisyah, N. (2016). An analysis of teachers' talk in an EFL classroom. Journal of English and Education, 4(2), 63-79.

Ali, J. M. (2000). Verbal communication: A study of Malaysian speakers. Kuala Lumpur: University of Malaya Press.

Alwasilah, A. C. (2002). Pokoknya kualitatif: Dasardasar merancang dan melakukan penelitian kualitatif. Jakarta: PT Dunia Pustaka Jaya.

Baxter, P., \& Jack, S. (2008). Qualitative case study methodology: Study design and implementation for novice researchers. The Qualitative Report, 13(4), 544-559.

Brown, H. D. (2007). Principles of language learning and teaching $\left(4^{\text {th }}\right.$ edn.). New York: Pearson Longman.

Chambliss, D. F., \& Schutt, R. K. (2013). Making sense of the social world, methods of investigation $\left(4^{\text {th }}\right.$ ed.). Thousand Oaks, CA: SAGE Publication.

Chaudron, C. (1988). Second language classrooms: Research on teaching and learning. Cambridge: Cambridge University Press.

Cope, B. (2007). How to plan for behaviour development and classroom management:
Maximising student engagement. New South Wales, Australia: Pearson Education.

Díaz-Ducca, J. A. (2014). Positive oral encouragement in the EFL classroom: A case study. Revista de Lenguas ModeRnas, 21, 325-346.

Dinkmeyer, D., \& Dreikurs, R. (1963). Encouraging children to learn. Englewood Cliffs, NJ: PrenticeHall.

Ferguson, M. (2013). Praise: What does the literature say? What are the implications for teachers? Kairaranga, 14(2), 35-39.

Flanders, N. A. (1970). Analyzing teacher behavior. New York: Addison-Wesley Publishing Co.

Gharbavi, A., \& Iravani, H. (2014). Is teacher talk pernicious to students? A discourse analysis of teacher talk. Procedia - Social and Behavioral Sciences, 98, 552-561. doi: 10.1016/j.sbspro.2014.03.451

Hai, S. K., \& Bee, L. S. (2006). Effectiveness of interaction analysis feedback on the verbal behavior of primary school Mathematics teachers. Jurnal Pendidik dan Pendidikan, 3(2), 115-128.

Harmer, J. (2007). How to teach English. Edinburgh: Pearson Education Ltd.

Krashen, S. (1982). Principles and practice in second language acquisition. Oxford: Pergamon.

Long, M. (1996). The role of the linguistic environment in second language acquisition. In W.C. Ritchke \& T.K. Bhatia. (eds.), Handbook of language acquisition: Second language acquisition (pp. 413468). New York: Academic Press.

Masrizal. (2014). The role of negotiation of meaning in L2 interactions: An analysis from the perspective of Long's Interaction Hypothesis. Studies in English Language and Education, 1(2), 96-105. doi: 10.24815/siele.v1i2.1829

Maulana, R., Opdenakker, M. C., Stroet, K., \& Bosker, R. (2012). Observed lesson structure during the first year of secondary education: Exploration of change and link with academic engagement. Teaching and Teacher Education, 28(6), 835-850. doi: 10.1016/j.tate.2012.03.005

Menegale, M. (2008). Expanding teacher-student interaction through more effective classroom questions: From traditional teacher-fronted lessons to student-centred lessons in CLIL. Venice: Ca' Foscari University of Venice.

Milal, A. D. (2011). Indicators of practice of power in language classrooms. TEFLIN Journal, 22(1), 1-15.

Nurmasitah, S. (2010). A study of classroom interaction characteristics in a Geography class conducted in English: The case at year ten of an immersion class in SMAN 2 Semarang (Unpublished Master's thesis). Diponegoro University, Semarang.

Park, K. N. (2005). An analysis of teacher talk in primary EFL classrooms. Foreign Language Education, 12(3), 323-353.

Putri, F. G. (2014). An analysis of classroom interaction by using Flander Interaction Analysis Categories System (FIACS) technique at SMPN 13 Kota 
Bengkulu in 2013/2014 academic year (Unpublished Bachelor's thesis). University of Bengkulu, Bengkulu.

Reigel, D. (2005). Positive feedback loops in second language learning. (Unpublished thesis). Portland State University, Oregon.

Saba, F. (2007). Postmodern theory of distance education, distance education system of the future. Journal of Education Technology System, 17(1), 215-250.

Setiawati, L. (2012). A descriptive study on the teacher talk at EYL classroom. Indonesian Journal of Applied Linguistics, 1(2), 33-48. doi: 10.17509/ijal.v1i2.83

Suryati, N. (2015). Classroom interaction strategies employed by English teachers at lower secondary schools. TEFLIN Journal, 26(2), 247-264. doi: 10.15639/teflinjournal.v26i2/247-264

Tuan, L. T., \& Nhu, N. T. K. (2010). Theoretical review on oral interaction in EFL classrooms. Studies in Literature and Language, 1(4), 29-48.

Walsh, S. (2002). Construction or obstruction: Teacher talk and learner involvement in the EFL classroom.
Language Teaching Research, 6(1), 3-23. doi: $10.1191 / 13621688021 \mathrm{r} 0950 a$

Wang, H. (2014). The analysis of teacher talk in "learner-centered" teaching mode. International Journal of Social, Behavioral, Educational, Economic, Business and Industrial Engineering, 8(4), 1172-1174

Yanfen, L., \& Yuqin, Z. (2010). A study of teacher talk in interactions in English classes. Chinese Journal of Applied Linguistics, 33(2), 76-86.

Yanita, F., Yusuf, Y. Q., \& Gani, S. A. (2016). “Oke, any questions?" The questioning interaction in an EFL classroom. Proceedings of The $6^{\text {th }}$ Annual International Conference Syiah Kuala University (AIC Unsyiah) in conjunction with The 12th International Conference on Mathematics, Statistic and Its Application (ICMSA) (pp. 328-333). October 4-6, Banda Aceh, Indonesia.

Zambrano, G. B. (2003). Teacher talk at three Colombian higher education institutions. Paper presented at The IV Congreso Nacional de Investigaciones Lingüístico-FilológicasUniversidad Ricardo Palma. Lima, Peru. 